\title{
Lectura y retórica ${ }^{1}$
}

\section{Aldo Oscar Valesini}

¿Es lineal la lectura? Sin dudas, su ejecución requiere de una temporalidad irrenunciable, y la conciencia accede en sucesivas aperturas a los conceptos, las representaciones, las construcciones que se pueden obtener a partir del texto'. Sin embargo, no es únicamente la progresión de grafias o de fonemas lo que la constituye. Aunque necesaria, esta instancia adquiere una curiosa ambivalencia: desplaza su valor intrínseco, que es esencialmente medium, para permitir una presencia que se instaura en un margen entre el esquema de conceptos del texto y la posibilidad de construcción que ejerza el lector. Constituye un descifrar', el riesgo, la aventura de penetrar gradualmente en un tejido de ideas, objetos, vivencias, que silenciosamente pueblan la conciencia.

El proceso no se cristaliza en los sucesivos avances de sonidos (lectura en voz alta) ni en el reconocimiento de fonemas y morfemas (lectura silenciosa); lo hace en la instauración del significado. Es simple advertir que el texto no ofrece los significados acabados, procede mediante términos y ellos lo incitan, lo convocan. Entonces la lectura permite a la conciencia reconocer, evocar, hacer presentes los significados que ya pertenecen al lector. Antes que conocer permite reconocer, y antes que el exterior, ahonda en el propio interior de quien que despliega la lectura.

La lectura virgen, primaria, es una piedra que cae en el agua: rápidamente se hunde, desaparece, aunque queda transformada. Ésta no es la demora de lo secundario, del residuo, sino más bien es la demora que convierte, multiplica, transforma. Es el tránsito natural que conduce a la recuperación del interior antes que del exterior. ¿Queda la forma, el color, la textura de la piedra? No, lo que perdura es una suerte de temblor en la superficie del agua que encubre las formas originales para insinuar otras, una reiterada expansión de círculos concéntricos, un aleteo donde se duplica levemente el ruido sordo del encuentro. Así la lectura asume esa condición que niega su propio origen, o que lo requiere para abandonarlo, y convocar una red de sonidos, imágenes, sensaciones, o tal vez historias que -cercanas o lejanas en la memoria- nos habitan. La lectura traiciona -olvida- lo que fue, y lo sustituye por un horizonte de naturaleza ajena. Tal vez recupera la entonación, la pausa, la sonoridad de las aliteraciones o el apuro de las sinalefas. Nada más. Lo demás es obra del que lee, porque el verbo leer dice mucho más que lo que suponemos.

En ese proceso dispar y en cierto modo azaroso, hay, sin embargo, modelos estructurales que permiten vislumbrar su funcionamiento, aunque no será posible descifrar la química generadora de cada imagen que cierra -transitoriamente-, el proceso. Wolfgang Iser, Stanley Fish, Hans-Robert Jauss, Roman Ingarden, entre otros han abordado esta cuestión en el marco de los estudios de la recepción o de la reacción estética'.

Las mismas oscilan entre la afirmación de los postulados de la hermenéutica de HansGeorg Gadamer y el desarrollo de las nociones pragmáticas que sustentan el análisis actual de la comunicación. Sin embargo, esta cuestión ya fue considerada en el Cratilo de Platón en relación con la naturaleza pragmática (comunicativa) del lenguaje desde la antigúedad clásica, y la retórica ha planteado sesgadamente su relevancia en relación con el estudio de la dispositio. 
La dispositio ofrece niveles de análisis que admiten su entidad significativa más allá de los aspectos formales de la organización textual: el significado y el sentido del texto emergen no solamente del costado semántico del discurso, sino también de la articulación de los componentes verbales mediante la gramática y la retórica. Es necesario recuperar el locus privilegiado de esta dimensión para comprender el funcionamiento de los procesos que regulan la comprensión del texto. A diferencia del significado del enunciado, la dispositio ejerce un poder autoritario: dice qué, cómo y cuándo, y no admite el diálogo. En el texto, nada más encubierto y estable que el inocente y casi inadvertido modelo. Asimismo, se introduce en la lectura y manipula el tiempo que le concedemos.

Tanto la hermenéutica como la pragmática linguística proponen una discusión que incumbe de manera decisiva a las nociones de comprensión y de interpretación, especialmente en cuanto categorías que residen en los procesos -esencialmente históricos- de la lectura antes que en la materialidad objetiva del texto cerrado. Umberto Eco (1979) introdujo los conceptos de 'diccionario' y 'enciclopedia' para referirse al funcionamiento de las noción chomskyana de competencia. Frente a la impersonalidad de la comprensión, fundada en la remisión al inventario del significado de los términos, la interpretación requiere simultáneamente la intervención del sujeto, quien aporta el peso histórico (individual y social) del significado. La enciclopedia es virtual, y materializa las posibilidades individuales de insertar el texto en el horizonte de la propia historia. Al leer un texto, hay un gesto indescifrable pero constitutivo que consiste en expandir, como condición, las propias posibilidades de comprender-para-sí.

La comprensión y la interpretación constituyen -en una complementariedad radical, a veces inadvertida- el cierre del itinerario iniciado en la lectura. Precisamente el espesor de cada una se define en relación con la distancia que el lector puede reconocer respecto de lo escrito. Esa distancia es inversamente proporcional a la distancia respecto de sí mismo. Es decir que en un polo se encuentra el texto, y en el otro, el mundo del sujeto: ambos proporcionan un material que puede leerse. Mientras el primero, materialmente es estable y uniforme, el otro sólo puede ser asido en el aquí y el ahora. Pocas veces un mismo texto literario convoca rigurosamente el mismo significado en dos ocasiones distintas de lectura. Esta errancia del yo, este constante expandirse y ordenarse en torno de diversas fuentes y soportes constituye el indecidible factor que otorga el carácter infinito a los textos. El problema -si lo queremos considerar como tal, en cuanto dimensión que no es posible objetivar en su totalidad a la manera behaviorista- no es el texto mismo, sino las operaciones que efectúa el lector.

\section{La alegoría}

Sostenemos que la lectura, considerada como un acto generador de significado y de sentido, a través de un tejido que obedece a reglas cuya complejidad supera las posibilidades de la explicación -lo que tienta a considerarla como una 'mise en abîme'"-, está regida por una operación retórica: la alegoria. Esta noción, sostenida por Paul de Man para fundamentar una práctica decontructiva en la praxis de la lectura, es en cierto modo constitutiva del proceso. Alude a ese relato que se interpone entre la materialidad del objeto de lectura y la conciencia que intenta aprehenderlo. 
La alegoria puede integrar un esquema de analogias que atiende a los dos modos de darse de los textos en el sujeto, con las correspondientes actividades radicadas en el espacio y el tiempo:

$$
\begin{array}{lll}
\text { Retórica } & \rightarrow & \text { Escritura } \\
\text { Alegoría } & \rightarrow & \text { Lectura }
\end{array}
$$

Esto permite advertir que la intencionalidad con que fueron relacionados en los términos del título es meramente relacional, no determinante. Tampoco significa que son excluyentes, sino por el contrario, ambos participan constitutivamente de la instauración del significado.

La misma trasposición de los términos en conceptos, en imágenes, en asociaciones, evocaciones, ideas, instaura en esa hendija un nuevo relato, traicionero casi siempre, puesto que nos convence de que es la imagen fiel reflejada en el texto. Sin embargo, hacemos con los textos lo que podemos. Ese poder, de todos modos, es crucial y universal, incluso democrático. De ahi en más, el texto nos provee de las indicaciones materiales, como si fueran los documentos de identidad: el autor, el título, el tema, el lugar de publicación, etc. Pero lo que incorporamos es la versión nuestra, particular, y nunca definitiva. La alegoría que nos acerca al texto se desarrolla unidireccionalmente en cuanto dispositio.

La lectura representa una instancia de duplicación de la escritura, en cuanto la conciencia -que subyace- pretende determinar las formas referenciales y retóricas de un texto, sustituir lo literal por lo figurado, desplegar el universo cognitivo, sensible, imaginativo en torno del lenguaje. Constituye el estadio pragmático que se instala en -0 sobre- el marco de la obra; recupera, de algún modo, la identidad del discurso, y lo modela a través de la alegoresis', una práctica en la que el texto adquiere su espesor significativo.

La alegoria -según Christian Vandendorpe- "s'applique d̀ la fois à des textes et d̀ un certain type d'operation de lecture."' Paul de Man sostiene la naturaleza fundamentalmente ética de la alegoría, y al hacerlo, asume la preeminencia de su consideración como una práctica de lectura'

Toda lectura supone una elección entre significación y simbolización, y esta elección sólo puede hacerse si se postula la posibilidad de distinguir lo literal de lo figurado. (...) No puede haber escritura sin lectura, pero todas las lecturas están en el error porque suponen su propia ilegibilidad. (...) podemos invertir la prioridad que nos hace concebir la lectura como consecuencia natural de la escritura. Resulta ahora que la escritura también puede ser considerada, con todo derecho, como correlato linguístico de la incapacidad de leer ${ }^{1}$.

La admisión de la lectura como una práctica que cuestiona la uniformidad entre el correlato referencial y el estatus linguístico de la obra, confiere a la secuencia 'alegoría' 'alegoresis' el estatuto de un proceso generador de una suerte de estrategia ambigua: decir dos veces', duplicar un decir no en el sentido propuesto por Michel Foucault, sino en la posibilidad de ampliar el constructo interpretativo. La alegoría pone en juego las relaciones de poder que el 
sujeto instaura sobre el referente. El texto alegórico no cautiva ${ }^{1}$, sino propone una praxis que es más bien un régimen de lectura que un procedimiento:

Lo que me gusta en un relato no es directamente su contenido ni su estructura sino más bien las rasgaduras que le impongo a su bella envoltura: corro, salto, levanto la cabeza y vuelvo a sumergirme. Nada que ver con el profundo desgarramiento que el texto de goce imprime al lenguaje mismo y no a la simple temporalidad de su lectura.'

Desde un punto de partida similar, aunque con un énfasis más orientado a la constitución de una epistemología, Paul de Man considera la posibilidad de establecer una mecánica deconstructiva del texto a partir de la alegoría' en relación con el estatus ontológico del lenguaje.

El interés del autor reside en detectar precisamente las aporías entre el relato contenido en el texto y el relato alegórico que subyace oculto, contradictorio, incesante en la lectura. El conflicto entre lo literal y. lo figurado, entre la materialidad del lenguaje y la interpretación legitima la estrategia alegórica como una condición que instala la duplicación incesante de sentido. El sentido del texto adquiere organicidad en la medida que lo hacemos inteligible merced a "un acuerdo predeterminado en cuanto a su autoridad referencial" (1990:234). No obstante, seffala su arbitrariedad ("es meramente contractual, nunca es constitutivo"). Este rasgo, que libera al lenguaje -literario- de la servidumbre referencial, contiene la posibilidad de generar las sucesivas inversiones que descentran su jerarquía significativa en su relación con lo externo al lenguaje, y al mismo tiempo recuperan las posibilidades contenidas en la morfología retórica -metafórica- de la obra.

El paradigma de todos los textos consiste en una figura (o un sistema de figuras) y en su deconstrucción. Pero, dado que este modelo no puede ser clausurado mediante una lectura final, engendra, a su vez, una superposición figurada suplementaria que narra la ilegibilidad de la narración anterior. En la medida en que tales narraciones se distinguen de las narraciones deconstructivas primarias, centradas en figuras $y$, en última instancia, en la metáfora, podemos llamarlas alegorías en un segundo (o un tercer) grado. Las narraciones alegóricas cuentan la historia del fracaso de leer, mientras que las narraciones tropológicas (...) cuentan la historia del fracaso de denominar.'

Alegoria y metáfora se constituyen en el anverso y el reverso de la obra en cuanto discurso: a ellas corresponden la práctica de la lectura y de la escritura. Ambas establecen el soporte sobre el que acontece el significado, abriendo -fisurando- la textura material del léxico para suplementarlo con la mala lectura ineludible. La textualidad se determina entonces no como el centro del scriptum, sino como una instancia convocante de una serie de alegorías que, sin afán de dar cuenta del significado, propicia la producción de planos incesantes cuya 
integridad sólo conduce a la demistificación ${ }^{1}$ del texto en relación con las distintas interpretaciones que se diseminan y lo diseminan.

La lectura desplaza su matriz desde la referencia hacia el lenguaje mismo, no en cuanto materialidad, sino como el continente de las representaciones, de las alegorías subrepticias. El proceso realizado en la búsqueda del significado consiste en generar narraciones cuya localización prescinde de la temporalidad y la espacialidad del texto, y se articula en las coordenadas del acto constructivo, que también es creativo.

La literatura es alegórica, entonces, no por su inmediato propósito aleccionador', como en el origen; su eticidad natural se funda en el acto mismo de atravesar los límites del lenguaje para convertirse en un significado en el horizonte de los posibles que la tradición ${ }^{1}$ ofrece al intérprete. La autorreferencialidad, en este caso, es puesta en cuestión merced a la dinámica de la lectura que siempre fagocita los espacios exteriores, a través de un esquema dialéctico.

La productividad de la lectura, entendida como la incitación subrepticia a generar nuevos significados, nuevas interpretaciones, consiste no en la progresión temporal de los conceptos, sino en la instauración de nuevas alegorías. La productividad es el proceso dinámico que permite la apropiación de aquel margen de la obra que ilumina lo que la conciencia reconoce como difuso e inquietante, en la zona de contacto entre lo exterior y el interior.

En síntesis, la lectura escenifica una competencia en el encuentro de dos "yo" a través de sus respectivas alteridades: la metáfora que provee el autor; la alegoría que produce el lector. La lectura pone en nuestra voz, en nuestra intimidad, en nuestro estar ahi las representaciones propuestas por el texto, y a través de él, en definitiva, accedemos a la alegoría que nos relata ese texto elemental que trata sobre nuestro propio rostro, imagen genuina que está presente inadvertidamente.

Tras la aparente escisión del sujeto a partir de la dialéctica entre el texto y la alegoría, la lectura propicia precisamente el encuentro, la afirmación del yo, pero no en un sentido tautológico, consistente en un retorno al lugar de partida. Representa una ampliación del horizonte, un locus donde se proyectan las representaciones, renovadas, animadas por nuevas relaciones. Pone en evidencia nuestra capacidad de recordar, imaginar, crear, lo que constituye una gesto autorreflexivo, pero también una apertura a la incorporación de nuevos modos del ser, del pensar, del imaginar, del saber. El significado, el sentido, acontecen entonces en un movimiento especular que nos reclama la libertad, la euforia de reconocer que somos, aunque fundando otro itinerario del ser. 